Turkish Online Journal of Qualitative Inquiry (TOJQI)

Volume 11, Issue 1, January 2020: 56-84

DOI: $10.17569 /$ tojqi.621543

Research Article

\title{
Teachers Opinion about Support Program in Primary Schools (SPPS)
}

\author{
Hüseyin Anılan ${ }^{1}$, Kübra Özgan ${ }^{2}$
}

\begin{abstract}
The aim of this study is to examine the opinions of teachers' about the Support Program in Primary Schools (SPPS) implemented in the 2018-2019 academic years. In this study, which is based on qualitative research, the study group consisted of 18 teachers who were determined with maximum diversity technique and criterion sampling technique. The data of the study was collected by semi-structured interview form and analyzed by content analysis. As a result of the research, teachers believe that the program is helpful for students in terms of providing students with one-to-one interest and compensating the deficiencies of the students. In addition, the participating teachers found that the SPPS materials are appropriate but suggested that the levels should be diversified. On the other hand, it was seen that teachers were not informed enough about SPPS. All of the teachers who participated in the research stated that the program had positive effects on the students and emphasized that the academic achievement of the students increased and their self-confidence and motivation towards the lesson increased.
\end{abstract}

Keywords: Support program in primary schools, SPPS, primary school, teacher opinions.

\footnotetext{
${ }^{1}$ Assoc.Prof.Dr., Eskişehir Osmangazi University, Faculty of Education, Department of Elemantary Education, anilan.huseyin@gmail.com, https://orcid.org/0000-0001-7201-7467

${ }^{2}$ Master Student, Eskişehir Osmangazi University, Institute of Education Sciences, kubraozzgan@.com, https://orcid.org/0000-0003-2130-0304.
}

Received: 18.09.2019, Accepted: 25.01.2020 


\title{
İlkokullarda Yetiştirme Programına (İYEP) İlişkin Öğretmen Görüşleri
}

\begin{abstract}
$\ddot{O} z$
Çalışmanın amacı, 2018-2019 öğretim yılında uygulamaya konan İlkokullarda Yetiştirme Programına (IYYP) ilişkin öğretmen görüşlerinin incelenmesidir. Nitel araştırmaya dayalı gerçekleştirilen bu araştırmanın çalışma grubunda amaçlı örnekleme tekniklerinden maksimum çeşitlilik tekniği ve ölçüt örnekleme tekniği ile belirlenmiş 18 öğretmen yer almaktadır. Çalışmanın verileri yarı yapılandırılmış görüşme formuyla toplanmış ve içerik analiziyle çözümlenmiştir. Araştırma sonucunda öğretmenlerin IYEP'i, öğrenciye birebir ilgi sağlaması ve öğrencilerin eksiklerini telafi etmesi yönüyle olumlu buldukları programın süresini ise yetersiz buldukları görülmüştür. Ayrıca katılımcı öğretmenler IYEP materyallerini uygun bulunmuşlar ancak seviyelerin çeşitlendirilmesi gerektiğini dile getirmişlerdir. Öte yandan öğretmenlerin IYYEP hakkında yeterince bilgilendirilmedikleri görülmüştür. Araştırmaya katılan öğretmenlerinin tamamı programın öğrenciler üzerinde olumlu etkilerinin olduğunu ifade etmişler, öğrencilerin akademik başarılarının yükseldiğini, öz güvenlerinin ve derse yönelik motivasyonlarının da arttı̆̆ını vurgulamışlardır.
\end{abstract}

Anahtar Sözcükler: İlkokulda yetiştirme programı, IYEP, ilkokul, öğretmen görüşleri. 


\section{Introduction}

Education is one of the main forces that provide social and economic development. In today's information age, it is essential for developing to improve the capacity of children' getting knowledge and using it. This capacity largely depends on the ability of the people of the country to acquire the skills of using mother anguage, numerical skills, communication skills and problem solving skills (Fidan \& Baykul, 1994). The basic education in which these skills are gained in solving the personal and social problems faced and faced in every citizen's life; to adapt to the values and regulations of society; productive and frugal basic competencies, is a training that gives habits (Başaran, 1982).

Basic education consists of the fundemantel of education and training in Turkey, likewise all over the world. In this context, Turkey has made significant progress in access to basic education and in the education academic year 2010/11 reached 98.4 percent enrollment in primary education in all countries. Although the gap between regions has quickly closed, the enrollment rate in some regions unfortunately continues to vary by region and gender (World Bank, 2011). Gender, socioeconomic status and school structures are the main variables of the inequality ofopportunity that emerged among students enrolled in school. Inequalities in each of these areas; qualified teachers, materials and structures of schools deepen inequalities between individuals and this has a negative impact on students' achievement (Oakes, 2004, p.345; Cited by Mete, 2009, p.2). On the other hand, studies show that the social benefit of investments in education is higher than the individual benefit. In this context, it is of utmost importance that education is provided on the basis of equality of opportunity and high quality (TÜSİAD, 2006).

Although significant progress has been observed in access to education, different studies are needed to improve quality and eliminate inequalities. For an equal and quality education in Turkey, which has always been debated some improvements need to be made. Reading, writing, reading comprehension skills and basic mathematic calculations can be considered as a positive step in raising the quality of education in order to reveal the individual learning needs of students in early classes and to plan a new system to support students. In this context, the development of the Support Program in Primary Schools (MEBb, 2018) is an important reflection of these efforts. 
Support Program in Primary Schools is a program applied to the education of the students who attend the third and fourth grades of primary schools, who do not have a special education diagnosis, who are included in the curriculum of Turkish and mathematics courses due to various reasons during the previous education and training years and who do not obtain the required qualifications within the scope of this program (MEBa, 2018).

Support Program in Primary Schools (SPPS) style programs are implemented in terms of education not only in Turkey but also developed countries which has successful economies. One of these is the "No Child Left Behind" project in USA. The share of immigrant children in the school age population increased from $6 \%$ in 1970 to $19 \%$ in 2000 . That is why in 2000, almost half (47\%) of primary school-aged children in California were immigrant children, and the success of those children left behind in education, including the children of immigrants, came to the fore (Capps et al., 2005). Based on this, in 2002, Bush started implementing the "No Child Left Behind" project in order to improve education and ensure equal opportunities. This law increased the responsibilities of schools on the academic achievement of students. The law covers several federal education programs. Each year, sub-group students are identified through exams that measure the level of students in language, mathematics and science courses and educational support is provided to these students (https://www.newamerica.org/educationpolicy/topics/federal-education-legislation budget/federal-education-legislation/essa/nclb/).

Again during the Obama administration, another project aimed at closing the gap between education and equal opportunities in education and success between the state and schools was created (https://www2.ed.gov/policy/elsec/leg/esea02/107-110.pdf). The ESSA law, signed by the Obama government on 10 December 2015, has similar aspects to "No Child Left Behind". Some suggestions have been made in ESSA, especially for the development of "No Child Left Behind" (https://www.understood.org/en/school-learning/your-childs-rights/basics-aboutchilds rights/thedifference-between-the-every-student-succeeds-act-and-no-child-left-behind). ESSAhttps://www.ed.gov/essa?src=ft).

Monica Olveire worked with the United Nations and UNICEF, focusing on the education of refugee children, assessing comparatively the education provided to refugee children in Europe within the framework of No Child Left Behind. In a study examining the education provided by Germany, France and the UK, Olveire stated that Germany offers the most powerful training 
program for immigrants, that France offers less individualized education and accepts less refugees. Monica Olveire also noted that the UK "No Child Left Behind" is strong in more liberal urban areas, such as London, but that the program is less effective in less metropolitan schools (https://tfurj.wordpress.com/2017/12/06/no-child-left-behind-a-comparative-study-ofchild refugee-education-policies-in-europe/).

Schlicht, Steffen \& Freitag (2010) gave the rates of social inequality in education of Western EU countries and Eastern EU countries and stated that there are significant differences between EU countries in terms of social inequality in education. Emphasized that the elimination of educational inequalities in general is not a realistic commitment, and stated that in the implementation of a policy, if measures are not sufficiently comprehensive or the policy does not target low social classes, the policy will not ensure equality in education at the intended level.

In Alcala, Spain, the No Child Left Behind project, similar to SPPS, was implemented and immigrant students were admitted to the school because the majority of the students (more than $50 \%$ ) were Moroccan students. As stated in the project, two difficulties were encountered in practice; the first was communication with the parents, and the second was the education of students with special educational needs. Like the Turkish part of SPPS program, English language education was given to foreign students and psychosocial support and integration studies were conducted as in SPPS (Campanar, 2016).

UNICEF, "No Child Left Behind" project aims to ensure that all children have the right to education free of charge, equal and with high quality. In twenty-one countries in Europe and Central Asia where UNICEF programs are implemented, studies are being conducted for children who are left behind in education (https://www.unicef.org/eca/our-mandate-no-childleft-behind). SPPS applied in Turkey is also supported by UNICEF financially.

In 20 of the 28 European Union countries, children are at greater risk of social exclusion and poverty than adults. In this context, "No Child Behind" project aims to ensure equal opportunities and opportunities not only in education but also in health. For example France; In November 2016, the Ministry of Health and the Ministry of National Education signed a contract for the prevention of disease and the protection of health. School environment; aims to fight against social inequalities and create health supporting environments. In Germany, the 
scope of the No Child Behind project has been broadened and the inequalities of children from pregnancy to working life have been tried to be eliminated (http://www.euro.who.int/en/mediacentre/sections/pressreleases/2016/12/europe-commits-to-leaving-no-child-behind).

Sardelic (2017) conducted a research on Roma children in the "No Child Behind Project" implemented in the European Union and as a result of this study, racist behaviors towards Roma children were mentioned. In contrast to SPPS; psychosocial support guide aims to support refugee students' adaptation to school and academic achievement.

In many OECD countries, income inequality has increased in recent years. Some researchers see poverty as worrying, while others are concerned about income inequality. In this sense, education policies are important. Policies that promote equality of opportunity in education also help reduce income inequality (OECD, 2012). As can be seen, programs similar to SPPS are being implemented in many countries for different reasons, especially migrants. However, these programs should be evaluated from time to time to develop. In this context, the aim of this study is to evaluate the SPPSs applied in our country by primary school teachers who are practitioners.

\section{Method}

\section{Research Design}

Qualitative research approach was adopted in this study which aims to evaluate SPPS according to the opinions of primary school teachers. Because during and after the collection of qualitative research, the researcher constantly tries to understand the data from the subjective perspectives of the participants. The most important task of qualitative research is to get the opinions of people who know the inside of the events (Christensen et al., 2015, p.54). During the qualitative evaluation process, the researcher aims to gain deep and detailed information about the success or failure of a project or program (Kuş, 2003, p.88).

\section{Participants}

The study group in this research consists of primary school teachers who have applied or are implementing SPPS in 2018-2019 academic years. When selecting primary school teachers in 
the study group purposeful sampling techniques; criterion sampling technique with maximum diversity was used. Purposeful sampling allows in-depth study of situations thought to be rich in information (Patton, 1997). The maximum diversity sampling is the determination of homogeneous different situations related to the problem examined in universe and the study is conducted on these situations (Büyüköztürk et. al. 2008, p.93). In this context, when selecting teachers; from Turkey's different regions and provinces attention has been paid to the fact that there are teachers who have different seniority years and provide education in different socioeconomic schools. The basic understanding of criteria sampling is to study all situations that meet a predetermined set of criteria. The criterion or criteria mentioned herein may be created by the researcher or a list of criteria previously prepared may be used (Yildirım \& Şimşek, 2006). The first criterion in the study was that the participants applied SPPS. The second criterion was the willingness/volunteer of teachers. Information about the teachers participating in the research is given in Table 1.

When Table 1 is examined, it can be seen that there are 18 primary school teachers (15 female and 3 male) in the study group. When the seniority years of the participants are examined, there are 8 teachers in the first five years, 6 teachers in 6-25 years and 4 teachers in 26-50 years. Looking at the grade level taught by the teachers, the combined classroom teacher is two, second grade teacher is four, third grade teacher is five and fourth grade teacher is seven. In the SPPS groups of the teachers participating in the research; there are three students of one teacher, four students of three teachers, five students of five teachers, six students of one teacher, eight students of five teachers, thirteen students of two teachers and twenty students of one teacher. In addition, Table 1 shows the modules in which teachers participating in the study started SPPS. 
Table 1.

Information about Teachers Participating in the Research and SPPS

\begin{tabular}{lllllll} 
& & & & \\
& & & & & \\
& & & & & & \\
& & & & & & \\
T1 & & & & & \\
T2 & Male & 10 & Primary School Teacher & 2 & 13 & Tesson and Module \\
T3 & Famele & 3 & Primary School Teacher & 4 & 5 & Math 2 \\
T4 & Famele & 3 & Primary School Teacher & $1,2,3,4$ & 4 & Turkish 1, Math 1 \\
T5 & Famele & 1 & Primary School Teacher & 4 & 8 & Turkish 3, Math 1-2 \\
T6 & Famele & 3 & Primary School Teacher & 3 & 8 & Math 3 \\
T7 & Famele & 2 & Primary School Teacher & 2 & 20 & Math 1 \\
T8 & Famele & 4 & Primary School Teacher & 3,4 & 5 & Turkish 2, Math 1 \\
T9 & Famele & 40 & Primary School Teacher & 3 & 5 & Turkish 1, Math 3 \\
T10 & Famele & 25 & Primary School Teacher & 3 & 5 & Turkish 2, 3, Math3 \\
T11 & Famele & 30 & Primary School Teacher & 4 & 5 & Turkish 2, Math 1 \\
T12 & Male & 21 & Primary School Teacher & 4 & 8 & Turkish 1, Math 1 \\
T13 & Famele & 31 & Primary School Teacher & 4 & 3 & Math 2 \\
T14 & Famele & 3 & Primary School Teacher & 2 & 8 & Math 1 \\
T15 & Famele & 22 & Department of Chemistry & 3 & 4 & Turkish 1, Math 1 \\
T16 & Male & 16 & Primary School Teacher & 2 & 8 & Turkish 1, Math 1 \\
T17 & Famele & 29 & Primary School Teacher & 4 & 4 & Turkish 1, Math 1 \\
T18 & Famele & 22 & Environmental Sciences & 4 & $13(7+6)$ & Turkish 3, Math 1 \\
\hline & & & & & & \\
\hline
\end{tabular}

\section{Data Collection Tools}

In the study, semi-structured interview form was prepared by the researchers in order to determine the opinions of the primary school teachers related to SPPS. While preparing the interview form, the literature was searched and the interview form was drafted considering the elements of the SPSS program and the course process. In the first stage, the draft of the semistructured interview form consisting of twenty-five questions was presented to two field experts and two primary school teachers. Following the suggestions and criticisms, the questions were reduced to fourteen and questions about the program were collected under five general titles. The interview form was presented to two field experts and two primary school teachers, and then a trial interview was conducted with two class teachers and the interview form was completed. 


\section{Research Process}

The semi-structured interview form provides first-hand access to opinions about the program and teacher experiences. Therefore, semi-structured interview form was used in the study. In semi-structured interviews, some parts of the interview are structured, some parts are not structured, and the questions allow the individual to react freely (Erkuş, 2005). Interviews target the determination of experiences of participants and how these experiences are shaped. In this study, semi-structured interviews with individual participants targeted their perspectives about the experiences and outcomes they gained during the process.

The interview questions were first conveyed to the participant and they were allowed to follow the flow of the interview if they wish. Nine participants were interview by appointment and face-to-face interviews. An online video call was made with the other nine participants. The interviews lasted a minimum of twenty and a maximum of thirty-five minutes. Data were collected between 20 March - 31 March 2019.

\section{Data Analysis}

In this research one of the qualitative data analysis techniques, content analysis technique was used. Content analysis is defined as a systematic renewable technique in which some words of a text are summarized in smaller content categories by coding based on certain rules (Büyüköztürk et al., 2008, p.259). Interviews with teachers for data analysis were written and organized. Afterwards, the responses of the participants were examined and the answers were divided into themes and codes. In this process categories and themes revealed by coding of data were used to interpret data. The coding process for data was separately completed by two researchers, then combined and consistency between coders was ensured.

\section{Validity and Reliability}

A quantitative study has to convince the reader that all procedures are strictly performed. Because there is little information about what any one and others are doing in this process. On the other hand, the qualitative study provides detailed descriptions that can convince the reader that the result is reasonable and logical (Sharan, 2009, p.200). In this context, in qualitative research, as in quantitative research, the reliability and validity determined with definite lines 
cannot be mentioned. Therefore, the researchers acted as impartially as possible while collecting the data, transcribed verbal statements in the interviews and analyzed these data in a systematic manner.

For the reliability study, the reliability formula (Reliability=Consensus/Consensus+ Disagreement) developed by Miles and Huberman (1994) was used for the reliability of the analysis of qualitative data. According to the reliability formula of Miles and Huberman, two different field experts encode and analyze the data according to pre-determined themes. Subthemes are created as a result of these encodings. Thus, the sub-themes that are agreed between experts and where there is a difference of opinion are determined and the reliability ratio can be determined by the reliability formula between the opinions of the two experts (Yanpar Yelken, 2009). As a result of the calculation, the reliability of the study was calculated as $92 \%$. Over $70 \%$ of reliability calculations are considered reliable for research (Miles \& Huberman, 1994). The result obtained in this context was considered reliable for the research.

\section{Findings}

In the analysis, the highest frequency expressions were themed in order to reflect the general opinion of the teachers, and these themes were detailed in the required parts with the codes. The themes and codes were supported by direct excerpts from teacher views. At any stage of the research, personal information of teachers was not provided and codes representing the participant were used. The research findings were grouped into five categories. The findings were presented under the themes.

\section{Findings about Teachers}

In this theme, teachers' opinions about whether they were informed enough about the program they are implementing and what they experienced while entering information into the e-School System were included. In this context teachers' opinions about knowing the program and their experiences regarding the e-School system are presented in Table 2 and in Table 3. 
Table 2.

Teachers' Opinions about Knowing the Program

\begin{tabular}{ll}
\hline Category & Example Teacher Thoughts \\
\hline $\begin{array}{l}\text { I have been } \\
\text { informed (N=6) }\end{array}$ & $\begin{array}{l}\text { My best source of information about the program was my director and } \\
\text { assistant manager. I was informed about the stages of the process...(T.6) }\end{array}$ \\
$\begin{array}{l}\text { I haven't been } \\
\text { informed } \\
\text { enough (N=8) }\end{array}$ & $\begin{array}{l}\text { I cannot say that I was sufficiently informed because no one had clear } \\
\text { knowledge because it was applied for the first time...(T.7) }\end{array}$ \\
& $\begin{array}{l}\text { I was informed by the seminar given by the National Education but it was } \\
\text { not enough. (T.8) }\end{array}$ \\
$\begin{array}{l}\text { I haven't been } \\
\text { informed (N=4) }\end{array}$ & $\begin{array}{l}\text { I researched it myself. I took advantage of the Education Information } \\
\text { I wasn't informed about the program. Information was inadequate. I think }\end{array}$ \\
& $\begin{array}{l}\text { it was November 12, SPPS started.... Preliminary information was } \\
\text { insufficient, but since we have been teaching for years, we acted with our } \\
\text { experience... (T.17) } \\
\text { On the day of the exam, we learned SPPS. The exam wasconducted... "Is } \\
\text { anyone volunteering?" was asked. So we informed...(T.11) }\end{array}$ \\
\hline
\end{tabular}

When Table 2 is examined; it was seen that the teachers' responses to informing about SPPS fall into three categories. Teachers' responses were that they were not sufficiently informed about SPPS. Participants who stated that they were not informed and those who stated that they did not provide sufficient information generally referred to the administration and the guidelines provided by Ministry of Education as the first source of information. While some participants also needed research themselves, some participants stated that years of experience were enough to cover the lack of information about the program.

Table 3.

Teachers' Opinions about e-School System

\begin{tabular}{ll}
\hline Category & Example Teacher Thoughts \\
\hline $\begin{array}{l}\text { I didn't have } \\
\text { difficulties or trouble } \\
(\mathrm{N}=13)\end{array}$ & $\begin{array}{l}\text { I don't have difficulty in entering information and reports to e-School. The } \\
\text { system is very practical. (T.14) }\end{array}$ \\
$\begin{array}{l}\text {..I have no problems with the e-School system; I am satisfied with the } \\
\text { system. (T.1) } \\
\text { System not opened }\end{array}$ & $\begin{array}{l}\text { We kept a notebook and a lesson plan. System not turned on. (Ö.11) } \\
\text { We kept a report with our guidance counselor. (T.13) }\end{array}$ \\
\hline
\end{tabular}

The e-School software is a web-based management information system, which provides accurate and fast information to educational administrators (school principals, provincial and district directorates and Ministry of Education) at all levels, which was implemented under the 
MEBBIS Project. In 2007, Ministry of Education launched e-School software. All primary education institutions affiliated to Ministry of Education have been using e-School since 2007 and secondary education institutions since 2008 (Bağlıbel et al., 2010, 2). The e-School system, which was put into use in 2007, is known to all by participants. Participants stated that they did not have any problems with the e-School system established for SPPS, and only five participants expressed problems related to the non-opening of SPPS's e-School system. The participants found the e-School prepared for SPPS in general practical and easy.

\section{Findings about Program}

Teachers' views on the program are grouped in four categories. The first is how they evaluate the program in general, the advantages and disadvantages of the program (Table 4), second, the level of effectiveness of SPPS (Table 5), third, evaluation of modules (Table 6) and finally, the Student Selection Tool (SST) and the Student Assessment Tool (SAT) (Table 7).

Table 4.

Teachers' Opinions about Curriculum

\begin{tabular}{|c|c|c|}
\hline Category & Codes & Example Teacher Thoughts \\
\hline \multirow{2}{*}{ 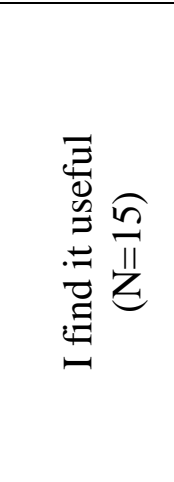 } & $\begin{array}{l}\text { Benefit and } \\
\text { advantages }(\mathrm{N}=6)\end{array}$ & $\begin{array}{l}\text { The program was very efficient for the students. Both parents } \\
\text { and students were very satisfied. (T.16) } \\
\text { I think it is very useful especially for those who teach in } \\
\text { combined classes like us. (T.8) } \\
\text {... He was very productive in intelligent refugee children. It } \\
\text { also worked well for children without family support. (T.17) }\end{array}$ \\
\hline & $\begin{array}{l}\text { Benefit and } \\
\text { disadvantages } \\
(\mathrm{N}=9)\end{array}$ & $\begin{array}{l}\text { It is a bit tiring to do the weekend but it is beneficial for the } \\
\text { students. (T.12) }\end{array}$ \\
\hline 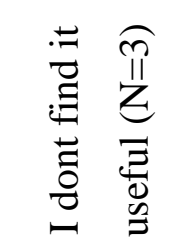 & \multicolumn{2}{|c|}{$\begin{array}{l}\text { The program does not serve its purpose, the books are simple and low level. (T.9) } \\
\text { I think it's an unnecessary practice in general. Because in my region (Eastern } \\
\text { Anatolia Region) students who joined SPPS fell behind their peers because of } \\
\text { problems such as absenteeism. They do not come to SPPS too. (T.3) }\end{array}$} \\
\hline
\end{tabular}

Fifteen respondents found the program useful, while three did not find it useful. Six out of fifteen participants who found the program useful were of the opinion that the program was advantageous. About the advantage; general statements were made that the program is beneficial for students who might be better off with some support. Nine participants mentioned 
the program as well as some disadvantages of the program.As a disadvantage, it was stated that the duration was not sufficient and the content was not sufficient. The three participants who did not find it useful suggested that different reasons such as the problem of attendance, the simplicity of the book contents and the lack of time.

Table 5.

Teachers' Opinions on the Effectiveness Level of SPPS

\begin{tabular}{lll}
\hline Category & Codes & Example Teacher Thoughts \\
\hline $\begin{array}{l}\text { Level } \\
\text { unreachable } \\
(\mathrm{N}=1)\end{array}$ & $\begin{array}{l}\text { SPPS is an effective program for students, but progress has not } \\
\text { reached the intended level. (T.1) } \\
\text { Insufficient } \\
\text { time (N=2) }\end{array}$ & $\begin{array}{l}\text { Difficult to achieve desired target but effective. (T.2) } \\
\text { The number hours of lesson is not enough. (T.18) }\end{array}$ \\
& $\begin{array}{l}\text { Absence } \\
\text { problem } \\
(\mathrm{N}=3)\end{array}$ & $\begin{array}{l}\text { A good practice for students who are able to continue, but } \\
\text { nothing can be done for a student who does not attend and comes } \\
\text { to class without a book. (T.7). }\end{array}$ \\
& $\begin{array}{l}\text { Enough } \\
(\mathrm{N}=12)\end{array}$ & $\begin{array}{l}\text { u.It was especially useful for refugee students. It was also very } \\
\text { (T.10) }\end{array}$ \\
& $\begin{array}{l}\text { I think it's effective because these students are unsuccessful } \\
\text { students in the class and discouraged children. One-to-one } \\
\text { interest in them enabled them to succeed... (T.11) }\end{array}$ \\
&
\end{tabular}

When Table 5 is examined, it is seen that all participants stated that SPPS is effective. However, twelve participants found the program effective and sufficient, while the other six participants mentioned some of the drawbacks of the program. Teachers stated that the program is effective but that if the students continue, there will be progress. Both teachers stated that the program was effective, but the periods were not sufficient. One teacher said that while the program was effective, there was some improvement but the desired level was not reached. Most of the teachers who evaluated the program as effective and sufficient stated that the program was effective because it provided one-to-one interest. In addition, some of the teachers were found to emphasize that SPPS improves students' self-confidence. 
Table 6.

Teachers' Opinions about Turkish and Mathematics Modules

\begin{tabular}{|c|c|c|}
\hline Category & Codes & Example Teacher Thoughts \\
\hline \multirow{3}{*}{ 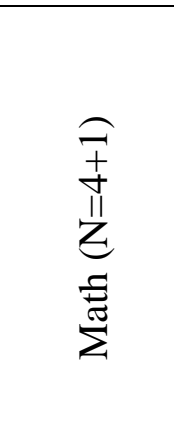 } & $\begin{array}{l}\text { Inadequate time } \\
(\mathrm{N}=3)\end{array}$ & $\begin{array}{l}\text { It had target and a time mismatch in the math module. } \\
\text { Because the time given in Module } 3 \text { was insufficient but the } \\
\text { gain was many... (T.6) }\end{array}$ \\
\hline & Easy $(\mathrm{N}=1)$ & Very easy. The book is beautifully prepared. (T.2) \\
\hline & $\begin{array}{l}\text { Suitability } \\
(\mathrm{N}=1)\end{array}$ & $\begin{array}{l}\text {...The mathematics module is better planned than the } \\
\text { Turkish module and the time allocated to the gains is } \\
\text { sufficient... (T.8) }\end{array}$ \\
\hline \multirow{3}{*}{ 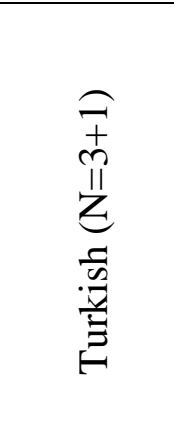 } & $\begin{array}{l}\text { Inadequate time } \\
(\mathrm{N}=1)\end{array}$ & $\begin{array}{l}\text { The third module devotes little time to reading } \\
\text { comprehension activities. (T.8) }\end{array}$ \\
\hline & Easy $(\mathrm{N}=2)$ & $\begin{array}{l}\text { Modules were good but Modules } 2 \text { and } 3 \text { were like repetition } \\
\text { of each other. The third module should focus more on } \\
\text { comprehension activity. (T.11) }\end{array}$ \\
\hline & $\begin{array}{l}\text { Problem with } \\
\text { book supply } \\
(\mathrm{N}=1)\end{array}$ & Turkish activity books did not reach the school. (T.18) \\
\hline \multirow{3}{*}{ 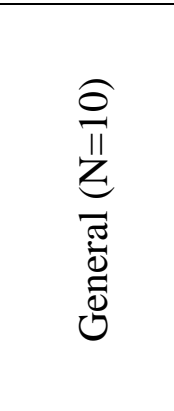 } & $\begin{array}{l}\text { Inadequate time } \\
(\mathrm{N}=1)\end{array}$ & $\begin{array}{l}\text { Time is inadequate for children who have difficulty } \\
\text { understanding. There is no time for repeat... (T.13) }\end{array}$ \\
\hline & Easy $(\mathrm{N}=4)$ & $\begin{array}{l}\text { Activities were easy in activity books. Levels of activities } \\
\text { were below student level. (T.9) }\end{array}$ \\
\hline & $\begin{array}{l}\text { Suitability } \\
(\mathrm{N}=5)\end{array}$ & $\begin{array}{l}\text { Modules are suitable for student level. (T.15) } \\
\text { The gains of the modules are given in accordance with the } \\
\text { student level. (T.1) }\end{array}$ \\
\hline
\end{tabular}

Looking at Table 6, the evaluation of the modules is divided into three categories. There are only four people evaluating the mathematics module. There are only three people evaluating the Turkish module. One of the participants also evaluated both Turkish and mathematics modules. This participant is +1 Ten participants evaluated the modules in general. Module headings combined into three categories are divided into codes with general expressions used by participants. About the mathematics module, three participants discussed the module duration. Stated that the given time was insufficient. One participant thinks that the math module is simple and another participant thinks that the math module is appropriate. Only one of the participants evaluating the Turkish module mentioned the module duration and found the duration insufficient. The two participants found the Turkish module simple and similar. Another participant stated that Turkish resources could not reach the school. Four of the 
participants who made a general evaluation of the modules found the modules simple and five found them appropriate. One participant stated that the periods were insufficient.

Tablo 7.

Teachers' Opinions about Student Selection Tool and Student Assessment Tools (SST - SAT)

\begin{tabular}{ll}
\hline Category & Example Teacher Thoughts \\
\hline $\begin{array}{l}\text { I didn't have } \\
\text { difficulty } \\
(\mathrm{N}=9)\end{array}$ & $\begin{array}{l}\text { I had no difficulty... (T.8) } \\
\text { The questions in Student Selection Tool and Student Assessment Tool are } \\
\text { understandable. There were no problems implementing. (T.6) }\end{array}$ \\
$\begin{array}{ll}\text { I had difficulty } \\
(\mathrm{N}=6)\end{array}$ & $\begin{array}{l}\text {...Not well understood. It was misunderstood SST. It could not distinguish } \\
\text { students much. (T.9) } \\
\text { It was difficult to apply in crowded classes... (T.18) }\end{array}$ \\
$\begin{array}{l}\text { I didn't } \\
\text { implemented } \\
(\mathrm{N}=3)\end{array}$ & $\begin{array}{l}\text { I haven't implemented it yet because of the class level I've taught. (T.14) } \\
\text {...Their primary school teachers evaluated. (T.15) }\end{array}$ \\
\hline
\end{tabular}

When Table 7 is examined, it is seen that teachers give opinions about three categories for SST and SAT. It is seen that the majority of the participants did not have any difficulty in applying the tools. Stating that they have difficulty, teachers emphasized the difficulty of practicing in crowded classrooms. Three teachers stated that they did not implement the tools.

\section{Findings Related to Materials and Contents}

Teachers' views on the SPPS materials and their contents were grouped in three categories. Accordingly, teachers' opinions about the materials are given in Table 8. The opinions of the Turkish and mathematics courses on the achievements are given in (Table 9). Their views on the duration of the modules (Table 10). 
Table 8.

Teacher' Opinions about Materials Prepared for SPPS

\begin{tabular}{|c|c|c|}
\hline Category & Codes & Example Teacher Thoughts \\
\hline $\begin{array}{l}\text { Effective and } \\
\text { adequate } \\
(\mathrm{N}=9)\end{array}$ & & $\begin{array}{l}\text { Prepared textbooks were very nice. (T.16) } \\
\text { The number of events is quite sufficient. They meets } \\
\text { the targets... (T.12) }\end{array}$ \\
\hline \multirow[t]{2}{*}{$\begin{array}{l}\text { Inadequate } \\
(\mathrm{N}=4)\end{array}$} & $\begin{array}{l}\text { Only Turkish } \\
\text { module } 3(\mathrm{~N}=2)\end{array}$ & $\begin{array}{l}\text { I found the number of texts insufficient in module } 3 \text { of } \\
\text { Turkish... (T.8) } \\
\ldots \text { Good for first stage but resources insufficient for } \\
\text { post-literacy... (T.17) }\end{array}$ \\
\hline & $\begin{array}{l}\text { Books } \\
\text { inadequate in } \\
\text { general }(\mathrm{N}=2)\end{array}$ & $\begin{array}{l}\text { I found the book inadequate. There should be more } \\
\text { practice and activity. (T.13) }\end{array}$ \\
\hline Easy $(\mathrm{N}=2)$ & \multicolumn{2}{|c|}{ Sources were simple. We made use of additional resources. (T.11) } \\
\hline \multirow{2}{*}{$\begin{array}{l}\text { Problem with } \\
\text { book supply, } \\
\text { but those who } \\
\text { reached were } \\
\text { good }(\mathrm{N}=3)\end{array}$} & \multicolumn{2}{|c|}{$\begin{array}{l}\text { Resource is sufficient for module } 1 \text {. Module } 2-3 \text { resources did not reach } \\
\text { the school. (T.18) }\end{array}$} \\
\hline & \multicolumn{2}{|c|}{$\begin{array}{l}\text { SPPS resources reached with a delay of one to two weeks and we could not } \\
\text { reach the teacher's guide book. Activities in the book are understandable... } \\
\text { (T.6) }\end{array}$} \\
\hline
\end{tabular}

Considering the information given in Table 8, teachers' opinions about the sources prepared for SPPS are gathered around four categories. "Insufficient" category is divided into two subcategories. Nine participants found the materials sufficient and four participants stated that the materials were insufficient in Table 8. Two of the four participants stated that the materials were insufficient, especially for the Turkish course and the other two gave general opinions. Two participants made a general assessment that resources were simple. Three participants stated that although they had difficulties in accessing resources, they were satisfied with the resources they received.

Table 9.

Teachers' Opinions about Turkish and Mathematics Course Objectives

\begin{tabular}{|c|c|}
\hline Category & Example Teacher Thoughts \\
\hline Adequate $(\mathrm{N}=13)$ & $\begin{array}{l}\text { Targets are appropriate. (T.14) } \\
\text { Objectives are suitable for students at this level. (T.12) }\end{array}$ \\
\hline $\begin{array}{l}\text { Easy } \\
(\mathrm{N}=2)\end{array}$ & $\begin{array}{l}\text { Below the level. (T.9) } \\
\text { It was simple. (T.10) }\end{array}$ \\
\hline $\begin{array}{l}\text { Should be } \\
\text { expanded }(\mathrm{N}=2)\end{array}$ & $\begin{array}{l}\text { Targets should be expanded. (T.4) } \\
\text { Targets should be increased... (T.13) }\end{array}$ \\
\hline $\begin{array}{l}\text { By student group } \\
(\mathrm{N}=1)\end{array}$ & $\begin{array}{l}\text { Efficient for refugee students but it was simple for Turkish students. } \\
\text { (T.11) }\end{array}$ \\
\hline
\end{tabular}


Considering the information in Table 9, the targets were found to be appropriate by the majority of teachers who were appropriate, adequate and appropriate to the level. Two teachers think that the gains should be expanded and both teachers think that the gains are simple. One teacher made evaluations according to student groups found, the gains appropriate for foreign students and found simple for Turkish students.

Table 10.

Teachers' Opinions on the Projected Times for Each Module

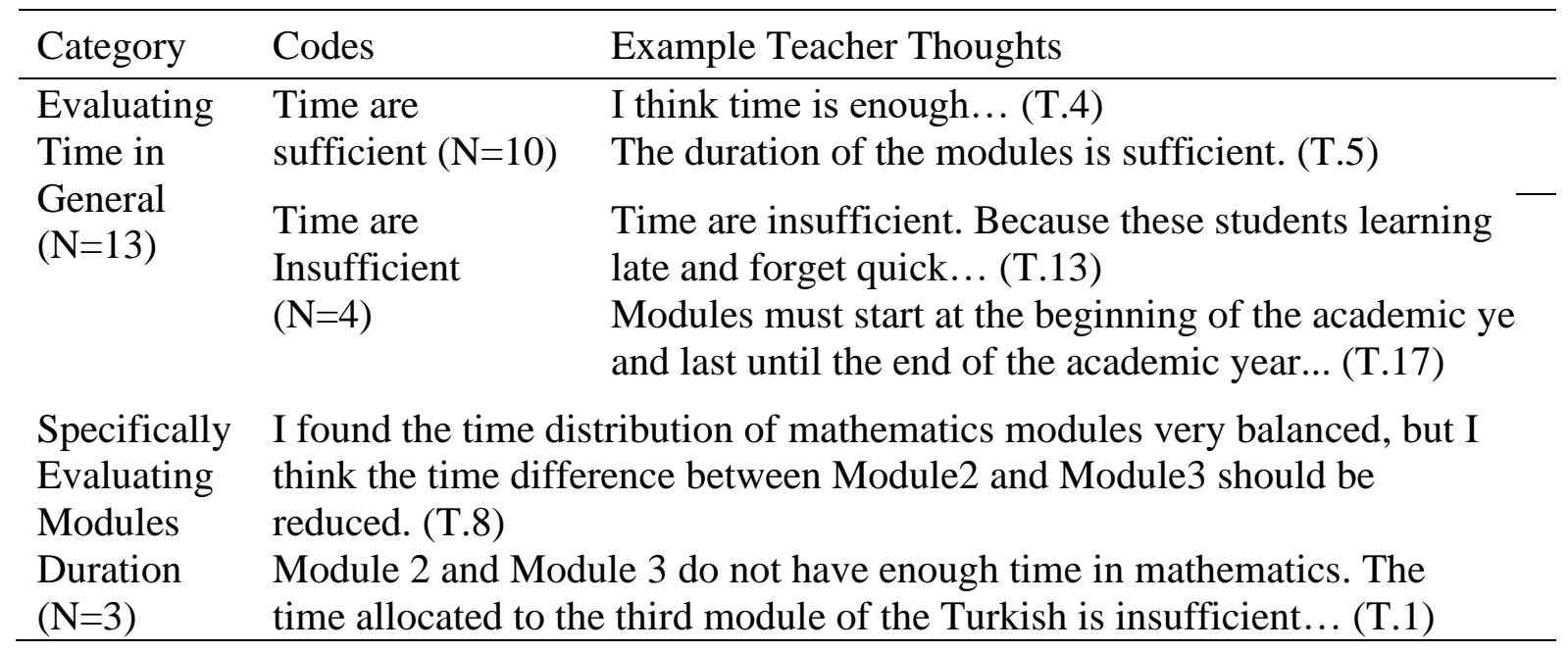

As can be seen in Table 10, thirteen teachers evaluated the time in general.Three teachers made a special assessment. One participant did not evaluate the times. Ten participants considered that the periods were sufficient. Four participants felt that the durations were insufficient. Three participants evaluated in the context of the time the modules and have made suggestions in this regard.

\section{Findings about the Student}

Teachers' views on students are divided into three categories. The first one is how students participating in SPPS are affected by the program. The second is the status of students who are included in the program because of they do not have be diagnosed. Finally, in the context of the psychosocial support guide, teachers take measures to ensure that students don't get separated from their peers. 
Table 11.

Teachers' Opinions on the Effects of SPPS on Students

\begin{tabular}{ll}
\hline Category & Example Teacher Thoughts \\
\hline $\begin{array}{l}\text { Self- } \\
\text { confidence } \\
\text { (N=3) }\end{array}$ & $\begin{array}{l}\text { There was a significant increase in students' participation in lesson and their } \\
\text { confidence. Parents are also satisfied. (T.1) } \\
\text { Taking lessons separately from their friends affected them negatively. They } \\
\text { exhibited behaviors such as shame and shyness. But when they saw they could } \\
\text { do right, these behaviors were replaced by self-confidence and desire. (T.8) }\end{array}$ \\
& $\begin{array}{l}\text { Absolutely positive for both students and parents. (T.2) } \\
\text { Positive } \\
\text { (N=5) }\end{array}$ \\
$\begin{array}{l}\text { I observed positive changes. Parents also think positive. (T.13) } \\
\text { (N=7) }\end{array}$ & $\begin{array}{l}\text { Some students progressed. (T.7) } \\
\text {...As the levels are equal in this class, cooperation and communication }\end{array}$ \\
between children improved in a better way. (T.5) \\
Happy
\end{tabular}$\quad \begin{aligned} & \text {...Children were happy because the teacher took care of the children one to one. } \\
& \text { The parents were not interested... (T.10) } \\
& \text { The parents of my students were not interested at all. But the students were very } \\
& \text { happy... (T.11) }\end{aligned}$

Table 11 shows that all the participants said the program had positive effects on the students. Accordingly, it was seen that three participants increased the students' "self-confidence", five participants focused on the word "positive" seven participants emphasized the increase of students' "academic achievement” and three participants emphasized the students' “emotional state".

Table 12.

Teachers' Opinions about Students Who are not Diagnosed with Special Education but are Included in SPPS

\begin{tabular}{ll}
\hline Category & Example Teacher Thoughts \\
\hline $\begin{array}{l}\text { No problem } \\
\text { N=12) }\end{array}$ & $\begin{array}{l}\text { I think that the students' deficiencies are eliminated. (T.12) } \\
\text { Not categorizing children shows children that they can do better. (T.18) }\end{array}$ \\
$\begin{array}{l}\text { Problem (N=5) } \\
\text { It was exhausting for students who did not have special education } \\
\text { diagnosi. I don't think the result will be achieve. (T.3) } \\
\text { Causes different problems. I have a student that she has not been } \\
\text { diagnosed who forget and with a perception problem. ...My student is } \\
\text { not progressing...It was a bit difficult. (T.17) }\end{array}$ \\
$\begin{array}{l}\text { The family did not send the child because of the concern of his child } \\
\text { send (N=1) }\end{array}$ & \begin{tabular}{l} 
being stigmatized... (T.9) \\
\hline
\end{tabular}
\end{tabular}


The number of teachers who do not see any harm in the participation of students who have special education needs and who are not diagnosed is twelve. In fact, some of these twelve teachers stated that this was beneficial for the students. Five teachers stated that the situation was a problem. The teachers who stated that there was a problem generally stated that these students did not make progress.

Table 13.

Teachers' Opinions of Weathering Feeling from Peers

\begin{tabular}{|c|c|}
\hline Category & Example Teacher Thoughts \\
\hline $\begin{array}{l}\text { Positive progress } \\
(\mathrm{N}=2)\end{array}$ & $\begin{array}{l}\text {...Students who did not communicate in the classroom started to } \\
\text { communicate better when they attended the course. (T.1) }\end{array}$ \\
\hline $\begin{array}{l}\text { Other students envied } \\
\text { them }(\mathrm{N}=2)\end{array}$ & ...Sometimes I take other students on a course. (Ö.3) \\
\hline They didn't feel $(\mathrm{N}=5)$ & $\begin{array}{l}\text {...I did not make the students feel that they were taking the } \\
\text { course because their level was low for the course. That's why } \\
\text { they don't know they came to the course. They don't have the } \\
\text { feeling of leaving their peers... (T.5) }\end{array}$ \\
\hline $\begin{array}{l}\text { One-on-one interest } \\
(\mathrm{N}=4)\end{array}$ & $\begin{array}{l}\text { They don't feel segregation because it's one-on-one interest. They } \\
\text { were very pleased from one-on-one attention. They felt } \\
\text { discredited before but when they joined SPPS they felt } \\
\text { themselves at the center of the incident... (T.11) }\end{array}$ \\
\hline They are happy $(\mathrm{N}=2)$ & They do not feel segregation, they are happy. (T.10) \\
\hline $\begin{array}{l}\text { Applied outside lessons } \\
\text { hours }(\mathrm{N}=2)\end{array}$ & $\begin{array}{l}\text { They did not feel bad because SPPS was applied outside lessons } \\
\text { hours. Have positive effects. (T.9) }\end{array}$ \\
\hline Troubled $(\mathrm{N}=1)$ & We are having trouble because the class level is mixed. (T.14) \\
\hline
\end{tabular}

As seen in Table 13, the majority of students did not have the feeling of separation. Two participants stated that there was a positive improvement in their communication in contrast to the feeling of separation of students. Two participants mentioned that SPPS was envied by other students. Five participants mentioned prevented students from feeling bad. Two participants emphasized that SPPS course is out of school hours. Only one participant stated that they had problems.

\section{Findings about Cooperation and Assistance}

Teachers' views on cooperation are divided into two categories. The first is the views on parents and the second is the views on cooperation with school counselors. 
Table 14.

Teacher Opinions Regarding SPPS Parents

\begin{tabular}{ll}
\hline Category & Example Teacher Thoughts \\
\hline $\begin{array}{l}\text { I can't get support } \\
\text { from parents (N=8) }\end{array}$ & $\begin{array}{l}\text { Parents are not interested. Children would be successful if parents } \\
\text { were concerned about their children. (T.4) } \\
\text {..I cannot communicate very well because parents are not very } \\
\text { interested in students. (T.7) }\end{array}$ \\
& $\begin{array}{l}\text { I cooperate with the parents. I'm telling them what their children } \\
\text { will learn. That's why the parents are happy. (T.9) }\end{array}$ \\
I'm collaborating & $\begin{array}{l}\text { We are in constant communication with parents about the situation } \\
\text { of children. (T.18) }\end{array}$ \\
Parents satisfied & $\begin{array}{l}\text { Parents send students with great enthusiasm. Parents are very } \\
\text { satisfied. (T.12) }\end{array}$ \\
\hline
\end{tabular}

Table 14 shows that teachers evaluate parents in three categories. Accordingly, eight teachers stated that they did not receive any support from the parents. Most of these eight teachers; complained that the parents were not concerned with their children.Six teachers stated that they kept the parents informed and the parents were helpful. All four teachers expressed their satisfaction with the program.

Table 15.

Teachers' Opinions about the Contribution of School Counselors to the Program

\begin{tabular}{ll}
\hline Category & Example Teacher Thoughts \\
\hline $\begin{array}{l}\text { We are cooperating } \\
\text { N=9) }\end{array}$ & $\begin{array}{l}\text { I cooperate with the school counselor. For example there were } \\
\text { students who lost some members of their families in SPPS class. } \\
\text {..I've been careful. I also received help for students to continue. } \\
\text { (T.6) } \\
\text { I communicate with the school counselor for programming, } \\
\text { progress and etc. status. We solve the problems we face together } \\
\text {... (T.17) }\end{array}$ \\
& $\begin{array}{l}\text { The guidance teacher never helped. (T.9) } \\
\text { No contribution }(\mathrm{N}=3)\end{array}$ \\
Not in our school $(\mathrm{N}=5)$ & There is no guidance unit in our school. (T.4) \\
Not responsible $(\mathrm{N}=1)$ & Counselor is not responsible for this program (SPPS). (T.18)
\end{tabular}

Looking at Table 16, nine of the participants received help from the school counselor and communicated with the counselor. Three participants stated that the guidance teacher had no help. In addition, there was no guidance service in the school of five participants and one of the participants thought that the guidance teacher was not responsible for the program. 


\section{Discussion and Conclusion}

In this study, which aims to determine the opinions of teachers about the Support Program in Primary Schools which was put into practice in 2018, some results were reached in the light of the findings. The results obtained are presented in a related manner within the framework of the themes and categories created.

In the first theme, which includes pre-program information, participants think that they are not informed enough about the program they are implementing before the program. The study of Gönen \& Kocakaya (2006), which determines that the courses organized by the Ministry of National Education is not sufficient in terms of number and quality, also supports this opinion of teachers. In addition, in the study conducted by Gözütok et al. (2005) regarding the curriculum, the finding that the two-week in-service training given to teachers was not sufficient overlaps with the results obtained in this study. It may be a problem that teachers do not receive adequate in-service training after the program is established. Önen et al. (2010) stated that inservice training eliminates teachers' lack of information and increases teacher competence. This can be interpreted that improving the quality of in-service training for SPPS will have a positive effect on SPPS teachers.

Participants who stated that they did not have difficulty in entering information into the eSchool system prepared for SPPS welcomed the system positively. In this respect, the satisfaction of the participants with the e-School coincides with the work of Bayraktar (2017). By the participants; In the theme in which the program is evaluated in general, it is seen that there is an increase in students' academic success and course motivation as the program provides special attention to the student. This result is consistent with the lack of interest towards the student, which is one of the reasons for student failure in Altun's (2009) study. The structure of SPPS; Altun (2009) is very important as it compensates for the lack of interest and motivation which are the first two reasons of student failure. Teachers have also developed a general opinion that SPPS is useful.

The situation that stands out in the theme of the effectiveness of the program is that the program has an effect on the participants and there are different levels of positive progress for students. As stated by the participants, the fact that the number of students in the SPPS is low and that 
the program provides one-to-one interest to the students are among the strengths of the program. The result of the fact that the small number of students provided positive returns for both the student and the teacher coincides with the research results of Öğ̈̈lmüş \& Özdemir (1995) and Yaman (2006).

In the theme of the modules, participant views are focused on two points. Accordingly, some participants found the modules simple. Some participants found the intended objectives consistent with the content aspect. Although the participants found the modules simple, the fact that a large number of students needed and remained in the program, indicating that the quality of the students was low and the simplicity of the resources were prepared considering the student level.

SPPS program is prepared according to the selected gains from the existing program. Therefore, it is considered appropriate to associate Turkish and mathematics curricula with the studies when evaluating SPPS.

The evaluation of the Turkish module as simple and inadequate includes the same result as the study of Epçaçan \& Erzen (2008), It is in contradiction with the study in which Şahin (2007) evaluated the Turkish program. For SPPS prepared from Turkish curriculum it can be said that the result will change when the sample changes done. As a matter of fact, the results obtained by Şahin (2007) are in line with the opinions of the participants who evaluate the modules as appropriate and convenient. Gömleksiz, Sinan \& Demir (2010), it is concluded that the Turkish Curriculum is generally effective in applications related to the field of writing learning. This result coincides with the opinions that the modules are effective and appropriate.

Teachers' common opinion about SST and SAT is that measurement tools are not difficult. According to Çakan's (2004) research results, teachers find themselves insufficient about measurement tools. In this respect, Çakan's (2004) research contradicts the result of this research. Akata (2007) and Arda (2009) stated that teachers found alternative assessment methods mixed. However, the teachers in the SPPS did not have such concerns. In the studies conducted by Çelikkaya (2010) and Kabapınar \& Ataman (2010), the most important problem faced by teachers in using measurement tools is the crowded classes. A similar problem was encountered when applying SST in SPPS. However, this problem was not encountered since the SATs were applied only to students who received modules. Therefore, when applying SSTs, 
it is necessary to make sure that students understand the measurement tools correctly in crowd class.

When the sources were evaluated, teachers generally liked the sources. The critical part of the sources has been reading comprehension activities. These activities should be developed. At the same time resources are seen as simple. Since the education system in our country is prepared according to the level of middle level students, this education is very easy for some and difficult for some children (Yakut, 1997). When the themes were examined, this was also the case for SPPS.

SPPS is not an alternative to existing curricula or formal education system (MEBb, 2018). In this context, it is considered appropriate to support the research results with the existing researches about the gains. Most of the teachers found the gains appropriate and sufficient for the program. This is similar to the results of Bal (2008) on mathematics curriculum gains.

In the theme in which the duration of the program was examined, the majority of the participants found that the duration of the modules was sufficient. However, there are also participants who find their times inadequate. Aydin (2009) emphasized the time problem of the participants in the study in which teachers' opinions about the new primary education program were taken. In the study of Ünsal (2013), the participants mentioned the lack of time. These results show that participants have different expectations regarding duration.

All participants stated that the program had a positive effect on students. It has been said that students' academic achievement increased. It was also said that the students' motivation towards the lesson increased. Demir \& Budak (2016) stated that there is a significant relationship between motivation and mathematics achievement. This study also supports the relationship between motivation and success in SPPS.

Most teachers think positively about the participation of students who do not have a special education diagnosis in SPPS. Teachers said that these students can also progress. Rakap \& Kaczmarekda (2010) stated that teachers who had fewer students in their class considered the inclusion education as positive (Cited by Nayır, 2013). This research has reached the same conclusion with SPPS. All but one of the teachers stated that the students did not feel the separation. 
Positive parent-teacher relationship is also very important for the success of the student (Hill \& Taylor, 2004, Cited by Koç, 2018). Teachers who cooperate with parents stated that parents are very satisfied with the program. Turanl (2009) concluded that most of the parents and students do not believe that homework helps students understand the subject. However, SPPS provides students with one-to-one learning with the teacher at the school and is appreciated by the parents.

Çelenk (2003) concluded that children from families who have a supportive attitude in terms of education have higher achievements. Shaw (2008) and Sheldon (2003) concluded that family participation positively affected students' academic achievement. When the parent profile in SPPS is examined, it is seen that the parents are indifferent towards the student. This is in line with the results of Çelenk, Shaw and Sheldon's work.

Most of the teachers who have school guidance teachers in their school receive support from the guidance service. According to the study conducted by Bakioğlu \& Gayık Asyalı (2005), teachers who see the positive developments and changes resulting from the guidance activities and benefit from these changes are more willing to cooperate with the guidance teachers. This supports the findings in the SPPS.

\section{Recommendations}

- Program duration can be extended/The course hours of the modules can be increased.

- The quality of in-service training provided to teachers for the program can be improved.

- Effective measures can be taken to ensure students' attendance.

- Resources can be prepared in two different levels as "Simple and Difficult".

- The content of the resources can be expanded in terms of scope and number of activities.

- Research can be designed using different data collection techniques. 


\section{References}

Akata, A. (2007). Türkçe programıyla ilgili ölçme ve dĕgerlendirme sürecinin işlevselliği üzerine bir araştırma (Tekirdă̆ ili örneği) (Unpublished master's thesis). Abant İzzet Baysal University, Bolu.

Altun, S. (2009). İlköğretim öğrencilerinin akademik başarısızlıklarına ilişkin veli, öğretmen ve öğrenci görüşlerinin incelenmesi, Illköğretim Online, 8(2), 567-586, Retrieved 28 April, 2019, from, http://ilkogretim-online.org.tr

Arda, D. (2009). İlköğretim sınıf öğretmenlerinin 2005 öğretim programı ekseninde ölçme ve değerlendirme alanındaki yeterlilik ve görüşlerinin incelenmesi (Unpublished master's thesis). Marmara Üniversitesi, İstanbul.

Aydın, O. \& Özmen, Z. (2009). Yeni ilköğretim programı ile ilgili öğretmen görüşleri, M. Atatürk Ĕ̆itim Fakültesi Ĕ̆itim Bilimleri Dergisi, 30, 47-60.

Bağlıbel, M., Samancıoğlu, M., \& Summak, M.S. (2010) Okul yöneticileri tarafından e-Okul uygulamasının genişletilmiş teknoloji kabul modeline göre değerlendirilmesi, Mustafa Kemal Üniversitesi Sosyal Bilimler Enstitüsü Dergisi, 13, 331-348.

Bakioğlu, A., \& Gayık Asyalı, S. (2005). Rehber öğretmenlerin bulundukları kariyer evrelerine göre okul yönetimini algılayışlarının niteliksel olarak incelenmesi. M. Ü. Atatürk Ĕgitim Fakültesi Eğitim Bilimleri Dergisi, 21, 89- 110.

Bal, P. (2008). Yeni ilköğretim matematik öğretim programının öğretmen görüşleri açısından değerlendirilmesi. Çukurova Üniversitesi Sosyal Bilimler Enstitüsü Dergisi, 17(1), 5368.

Başaran, İ.E. (1982). Temel eğitim ve yönetimi. Ankara: Ankara Üniversitesi Eğitim Fakültesi Yayını No:112.

Bayraktar, D. (2017). e-Okul yönetim bilgi sisteminin kullanılabilirliğinin göz izleme yöntemi ile değerlendirilmesi, İnsan ve Toplum Bilimleri Araştırma Dergisi, 5, 2908-2928

Büyüköztürk, Ş., Çakmak, E. K., Erkan, Ö., Karadeniz, Ş., \& Demirel, F. (2008). Bilimsel araştırma yöntemleri (23.Basım) Ankara: Pegem Akademi

Capps, R., Fix, M., Murray, J., Ost, J., Passel, J., \& Herwantoro, S. (2005). The new demography of america's schools immigration and the no child left behind act, 
Washington, DC: The Urban Institute. Retrieved 20 May, 2019, from, https://files.eric.ed.gov/fulltext/ED490924.pdf

Campanar, C. L. (2016). No child left behind in europe, Retrieved 25 April, 2019, from, https://www.up2europe.eu/european/projects/no-child-left-behind-in-europe_93864.html

Christen, L.B., Johnson, R.B., \& Turner, L.A. (2015). Nitel araştırma, araştırma yöntemleri desen ve analiz. Aypay, A. (Çev. Ed.). (2.Basım) Ankara: Anı Yayıncılık.

Çakan, M. (2004). Öğretmenlerin ölçme-değerlendirme uygulamaları ve yeterlik düzeyleri: ilk ve ortaöğretim, Ankara Üniversitesi Eğitim Bilimleri Fakültesi Dergisi, 37( 2), 99-114.

Çelenk, S. (2003). Okul başarısının ön koşulu: Okul aile dayanışması, İlköğretim Online eDergi, 2(2), 28-34.

Çelikkaya, T., Karakuş, U., \& Demirbaş, Ç. (2010). Sosyal bilgiler öğretmenlerinin ölçme değerlendirme araçlarını kullanma düzeyleri ve karşılaştıkları sorunlar, Ahi Evran Üniversitesi Eğitim Fakültesi Dergisi, 11(1), 57-76.

Demir, M., \& Budak, H. (2016). İlkokul dördüncü sınıf öğrencilerinin öz düzenleme, motivasyon, biliş üstü becerileri ile matematik dersi başarılarının arasındaki ilişki, Buca Ĕ̌itim Fakültesi Dergisi, 41, 30-41.

Dünya Bankası (2011). Türkiye'de temel eğitimde kalite ve eşitliğin geliştirilmesi zorluklar ve seçenekler. Dünya Bankası, İnsani Kalkınma Departmanı, Avrupa ve Orta Asya Bölgesi. Retrieved 13 May, 2019, from, https://abdigm.meb.gov.tr/projeler/ois/egitim /007.pdf

Epçaçan, C., \& Erzen, M. (2008). İlköğretim Türkçe programının değerlendirilmesi, Uluslararası Sosyal Araştırmalar Dergisi, 1(4), 182-202.

Erkuş, A. (2005). Bilimsel araştırma sarmalı. Ankara: Seçkin Yayıncılık.

Fidan, N., \& Baykul, Y. (1994). İlköğretimde temel öğrenme ihtiyaçlarının karşılanması, Hacettepe Üniversitesi Ĕ̈itim Fakültesi Dergisi, 10, 7-20.

Gömleksiz, M., Sinan, A., \& Demir S. (2010). İlköğretim Türkçe dersi öğretim programındaki yazma öğrenme alanının etkililiğinin değerlendirilmesi, Turkish Studies International Academic Journals, 5(4), 1135-1173.

Gönen, S., \& Kocakaya, S. (2006). Fizik öğretmenlerinin hizmet içi eğitimler üzerine görüşlerinin değerlendirilmesi, Pamukkale Üniversitesi Eğitim Fakültesi Dergisi, 19(19), 37- 44. 
Gözütok, D., Akgün, Ö., \& Karacaoğlu, C. (2005). Yeni ilköğretim programlarının uygulanmasına öğretmenlerin hazırlanması. eğitimde yansımalar: VIII Yeni Illköğretim Programlarını Değerlendirme Sempozyumu 17-40, 14-16 Kasım Erciyes Üniversitesi, Sabancı Kültür Sitesi, Kayseri.

Kabapınar, Y., \& Ataman, M. (2010). İlköğretim sosyal bilgiler (4-5. Sinıf) programlarındaki ölçme ve değerlendirme yöntemlerine ilişkin öğretmen görüşleri, İlköğretim Online, 9(2), 776-791. Retrieved 28 May, 2019, from, http://ilkogretim-online.org.tr.

Kuş, E. (2003). Nicel nitel araştırma teknikleri, Ankara Anı Yayıncılık

Koç, M. H. (2018). Veli görüşlerine göre veli öğretmen ilişkisi ölçeğinin geliştirilmesi ve veli öğretmen ilişkisinin incelenmesi, Milli Ĕgitim Dergisi, 47, 217, 55-76.

MEBa, (2018) İlkokullarda yetiştirme programı yönergesi. Ankara: Milli Eğitim Bakanlığı, Temel Eğitim Genel Müdürlüğü. Retrieved 04 April, 2019, from, http://tegm.meb.gov.tr/meb_iys_dosyalar/2018_09/25181019_YYEP_YYNERGESY.pdf

MEBb, (2018). İlkokullarda yetiştirme programı uygulama k1lavuzu 2018-2019. Ankara: Milli Eğitim Bakanlığı, Temel Eğitim Genel Müdürlüğü. Retrieved 13 April, 2019, from,https://tegm.meb.gov.tr/meb_iys_dosyalar/2018_09/13134503_YYEP_Uygulama_KYlav uzu.pdf

Merriam, S.B. (2009). Nitel araştırma desen ve uygulama için bir rehber, Turan, S. (Çev. Ed.). (3.Basım) Ankara: Nobel Yayıncılık.

Mete Y.A. (2009). Fırsat eşitliği temelinde öğretmen atama politikalart-nesnel çözümleme/Öznel Tanıklıklar (Unpublished doctoral dissertation). Kocaeli Üniversity, Kocaeli.

Miles, M.B., \& Huberman, A. M. (1994). Qualitative data analysis: an expanded sourcebook. (2nd Edition). Calif. : SAGE Publications.

Nayır, F., \& Karaman Kepenekçi, Y. (2013). Kaynaştırma öğrencilerinin haklarına ilişkin sınıf öğretmenlerinin görüşleri, Ĕgitim Bilimleri Araştırma Dergisi,3(2), 69-89.

New America (2018). Edication policy. Retrieved 08 July, 2019, from, https://www.newamerica.org/education-policy/topics/federal-education-legislationbudget/federal-education-legislation/essa/nclb/.

No Child Left Behind: A Comparative Study of Child Refugee Education Policies in Europe (06.12.2017). The Fordham Undergraduate Research Journal. Retrieved 20 January, 
2019, from, https://tfurj.wordpress.com/2017/12/06/no-child-left-behind-a-comparativestudy-of-child-refugee-education-policies-in-europe/.

OECD, (2012). Reducing income inequality while boosting economic growth: Can it be done?, Economic policy reforms 2012, Going for Growth, Part:2, Chapter: 5. Retrieved 23 April, 2019, from, http://www.oecd.org/economy/labour/49421421.pdf

Öğülmüş, S., \& Özdemir, S. (1995). Sınıf ve okul büyüklüğünün öğrenciler üzerindeki etkisi. Eğitim Yönetimi Dergisi, 1(2). Retrieved 20 May, 2019, from, http://kuey.net/index.php/kuey\%20/article/view/776.

Önen, F., Mertoğlu, H., Saka, M., \& Gürdal, A. (2010). Hizmet içi eğitimin öğretmenlerin proje ve proje tabanlı öğrenmeye ilişkin bilgilerine ve proje yapma yeterliklerine etkisi: Öpyep Örneği, Ahi Evran Üniversitesi Eğitim Fakültesi Dergisi, 11(1), 137-158.

Patton, M. Q. (1997). How to use qualitative methods in evaluation. Newbury park, CA: Sage. Sardelic, J. (2017). No child left behind in the european union?: The Position of Romani Children, Journal of Social Welfare and Family Law, 39(1), 140-147.

Schlicht, R., \& Steffen, I. Freitag (2010). Educational inequality in the EU, the effectiveness of the national education policy, European Union Politics, 11(1) 29-59

Shaw, C.A. (2008). A study of the relationship of parental involvement to student achievement in a Pennsylvania career and technology center (Unpublished Doctoral Dissertation). The Pennsylvania State University. Pennsylvania, USA.

Sheldon, S.B. (2003). Linking school-family-community partnerships in urban elementary school to student achievement on state tests. The Urban Review, 35(2), 149-164.

Şahin, İ. (2007). Yeni ilköğretim 1. kademe Türkçe programının değerlendirilmesi, Elementary Education Online, 6(2), 284-304. Retrieved 08 May, 2019, from, http://ilkogretimonline.org.tr

Turanl1, S. (2009). Students' and paretns' perceptions about homework, Education and Science, $34(153), 61-73$

TÜSİAD, (2006). Eğitim ve sürdürülebilir büyüme: Türkiye deneyimi, riskler ve firsatlar. Yayın No; TUSİAD- 06-420. Retrieved 18 May, 2019, from, https://tusiad.org/tr/yayinlar/raporlar/item/3611-egitim-ve-surdurulebilir-buyume-turkiye-deneyimi--riskler-ve-firsatlar 
Understood Team, The. (2017). The difference between the Every Student Succeeds Act and No Child Left Behind. Retrieved August 7, 2017, from www.understood.org/en/schoollearning/your-childs-rights/basics-about-childs-rights/the difference-between-the-everystudent-succeeds-act-and-no-child-left-behind

Unicef (2018). Our Mandate: No child left behind. Retrieved August 7, 2018, from www.unicef.org/eca/our-mandate-no-child-left-behind

US Department of Education (2002). Public Law 107-110. Retrieved July 16, 2018, from https://www2.ed.gov/policy/elsec/leg/esea02/107-110.pdf.

Ünsal, H. (2013). Yeni öğretim programlarının uygulanmasına ilişkin sınıf öğretmenlerinin görüssleri, Illkögrretim Online, 12(3), 635-658. Retrieved 19 April, 2019, from, http://ilkogretim-online.org.tr

World Health Organization Regional Office for Europe (07.12.2016). Europe commits to leaving no child behind.

Yakut, A. (1997). Hangi yaşta hangi eğitim, İstanbul: Gençlik Yayınları.

Yaman, E. (2006). Eğitim sistemindeki sorunlardan bir boyut: Büyük sınıflar ve sınıf yönetimi, Türk Ë̆itim Bilimleri Dergisi, 4(3), 261-274.

Yanpar Yelken, T. (2009). Öğretmen adaylarının portfolyoları üzerinde grup olarak yaratıcılık temelli materyal geliştirmenin etkileri, Eğitim ve Bilim, 34, 83-98.

Yıldırım, A. Şimşek, H. (2006). Nitel araştırma yöntemleri. Ankara: Seçkin Yayınevi. 